2011. - № 2. - C. 36-37.

7. Суханова И.Ф., Лявина М.Ю. Совершенствование системы господдержки животноводства как инструмента политики импортозамещения // Аграрный научный журнал. - 2017. - № 12. - С. 92-95.

8. Чазова И.Ю. Организационно-экономический механизм устойчивого развития рынка овощей защищенного грунта: автореф. дис. ... канд. экон. наук. - Ижевск, 2017. - 24 с.

Бреднев Владислав Дмитриевич, аспирант ка- федры «Маркетинга и ВЭД», Саратовский государственный аграрный университет имени Н.И. Вавилова. Россия.

410012, г. Саратов, Театральная пл., 1.

Тел.: (8452) 26-27-83.

Ключевые слова: тенденции развития; производство; реализация; импортозамещение; овощи защищенного грунта.

\title{
CURRENT STATUS AND TRENDS OF DEVELOPMENT OF GREENHOUSE VEGETABLE'S PRODUCTION AND SALE UNDER CONDITIONS OF IMPORT SUBSTITUTION
}

Brednev Vladislav Dmitrievich. Post-graduate Student of the chair "Marketing and Foreign Economic Activity", Saratov State Agrarian University named after N.I. Vavilov. Russia.

Keywords: current status; trends of development; production; sale; import substitution; greenhouse vegetables.

The current status of development of greenhouse veg- etable farming sector is analyzed, central issues of business management in ground protected vegetable farming sector in modern conditions of import substitution are revealed, current special aspects of the development of greenhouse facility vegetable's production and sales are represented, prospects for the development of greenhouse vegetable farming sector enterprises are regarded.

УДК 630*644.7:631.145(045)

\section{ВЛИЯНИЕ КОЛЕБАНИЙ ЦЕН НА РАЗВИТИЕ АГРОБИЗНЕСА}

\author{
БУТЫРИН Василий Владимирович, Саратовский государственный аграрный университет \\ имени Н.И. Вавилова
}

\begin{abstract}
БУТЫРИНА Юлия Александровна, Саратовский государственный аграрный университет
\end{abstract} имени Н.И. Вавилова

МОРЕНОВА Елена Александровна, Саратовский государственный аграрный университет имени Н.И. Вавилова

ЧЕРНЕНКО Елена Владимировна, Саратовский государственный аграрный университет имени Н.И. Вавилова

Рассматривается влияние различных факторов на эффективность сельскохозяйственного производства на примере растениеводства. На основе расчетов доказывается, что наиболее сильное влияние на эффективность и развитие агробизнеса оказывает колебание иен на рынках сельскохозяйственной продукции.

Введение. На эффективность агробизнеса оказывают влияние различные факторов, которые по различным признакам можно классифицировать на разные группы : внешние и внутренние, природно-климатические и социально-экономические, организационные и технологические и т.п. Однако, не смотря на множество влияющих факторов и сложность характера их влияния, в конечном итоге, весь комплекс влияющих воздействий аккумулируется и определяет эффективность агробизнеса через несколько ключевых показателей, с помощью которых и рассчитываются конечные финансовоэкономические результаты деятельности агропредприятий: прибыль, доходность, уровень рентабельности производства и продаж. Рассмотреть данную систему влияния целесообразно на примере растениеводства, являющегося наиболее рискованной отраслью, подверженной воздействию как производственных, так и коммерческих рисков.
На эффективность данной отрасли, как и других отраслей, влияют рынок продукции и рынок ресурсов. Рынок ресурсов, оказывая опосредованное влияние через технологический процесс в конечном итоге приводит к формированию одного из ключевых результативных показателей - удельные затраты на 1 га посева той или иной культуры. Удельные затраты, аккумулируя влияние комплекса факторов при воздействии погодно-климатических условий формируют показатель урожайности культур и на основе ее величины определяют уровень себестоимости производимой продукции.

Урожайность - ключевой показатель эффективности в растениеводстве, величина которого на фоне низкого уровня применяемых технологий в большой степени зависит от погодно-климатических условий. Внедрение современных технологий возделывания культур позволяет снизить эту зависимость и существенно увеличить уровень 
урожайности культур. Это основной вектор развития отечественного растениеводства, которое по уровню урожайности пока еще в целом существенно отстает от развитых зарубежных стран. Однако внедрение технологических инноваций связано с дополнительными вложениями средств предприятий в материально-техническую базу, в приобретение ресурсов более высокого качества (семян, удобрений, средств защиты растений), в развитие кадрового потенциала [2]. Дополнительные затраты в технологические развитие производства имеют смысл только в том случае, когда они окупаются и позволяют получить дополнительные доходы. Это значит, что дополнительные затраты на технологические инновации должны, как минимум, не приводить к росту себестоимости или оправдывать ее определенное увеличение повышением качества продукции. Данная простая экономическая логика понятна большинству сельскохозяйственных товаропроизводителей и уже доказана опытом работы многих передовых фермеров и предприятий.

Цель исследования - рассмотреть влияние основных факторов на эффективность сельскохозяйственного производства на предприятиях Сaратовской области.

Методика исследований. В последние годы некоторые хозяйства Саратовской области, применяя современную технику и передовые технологии, достигают уровня урожайности культур, которые ранее были нереальными для данного региона. Например, при средней урожайности озимой пшеницы в области на уровне 20-25 ц/га, пе-

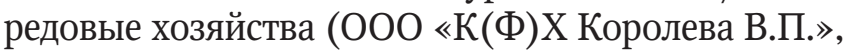
ООО «Земледелец-2002», ООО «Лада», К(Ф)Х Чернова В.А, К(Ф)Х «Деметра» и др.) достигают уровня 50-60 ц/га, а в благоприятные годы и до 80 ц/га. Эти положительные примеры подтверждают реальные возможности развития растениеводства на основе использования современных интенсивных технологий, однако данное направление роста пока не сложилось в устойчивую и массовую тенденцию.

Большинство сельскохозяйственных товаропроизводителей крайне осторожно и не охотно вкладывают средства в совершенствование технологий, поскольку окупаемость вложений зависит не только от себестоимости, формируемой рациональными затратами и полученной урожайностью, но и от уровня цен реализации, сложившихся на рынке.

Уровень цен, складывающихся на рынке готовой продукции в соотношении с полученным уровнем себестоимости, в конечном итоге, и определяет эффективность производства. Проблема заключается в том, что в настоящее время под воздействием факторов все три основных показателя - затраты на 1 га, урожайность и цена колеблются в значительных пределах, что приводит к изменениям уровня эффективности производства, обусловливая значительные риски и высокую нестабильность фи- нансовых результатов производственной деятельности.

С помощью расчетов несложно доказать, что из-за колебаний данных ключевых показателей производство продукции тех или иных культур может быть как прибыльным, так и убыточным. Это справедливо и для зерновых, и для других культур, возделываемых сельскохозяйственными товаропроизводителями Саратовской области. Выход из сложившейся ситуации только один - различными возможными методами обеспечить устойчивость основных показателей, формирующих эффективность производства продукции растениеводства.

Эффективное воздействие на уровень цен можно обеспечить только за счет системы государственного регулирования, которая позволит установить оптимальные и стабильные цены внутреннего рынка. Колебания урожайности под воздействием погодно-климатических факторов можно компенсировать только системой агрострахования объективных производственных рисков. Величина производственных затрат может регулироваться через соблюдение определенных технологических регламентов и оптимизацию технологических процессов с учетом природно-климатических зон возделывания культур. Технологические факторы также существенно влияют и на величину урожайности, позволяя в определенной степени минимизировать отрицательное воздействие погодно-климатических условий. Следует также отметить, что в настоящее время для стабилизации как производства, так и рынка сельскохозяйственной продукции важное значение имеет оптимизация структуры посевных площадей и севооборотов для обеспечения сбалансированного внутреннего рынка на основе межотраслевого планирования и формирования устойчивых кооперативных связей на локальных рынках.

Вместе с тем, не смотря на важность и значимость всех рассмотренных факторов и направлений преодоления их негативного воздействия, важнейшими из них, по нашему мнению, являются цены на сельскохозяйственную продукцию, а точнее их колебания как важнейший фактор эффективности агробизнеса, сдерживающий его инновационное развитие.

Значительные колебания уровня цен, наблюдающиеся в последние десятилетия, существенным образом дестабилизируют и сдерживают развитие сельскохозяйственного производства, не позволяют сформировать устойчивость в данном секторе экономики (рис. 1) [4].

Анализируя данные графика, можно увидеть, что обвалы цен на зерно происходят с определенной регулярностью и характерны для тех лет, когда благоприятные факторы позволяют производителям получать большие урожаи. Аналогичная ситуация сложилась и в прошлом 2017 г., когда из-за высокой урожайности и больших валовых сборов зерна цены и, соответственно, спрос на него упали 


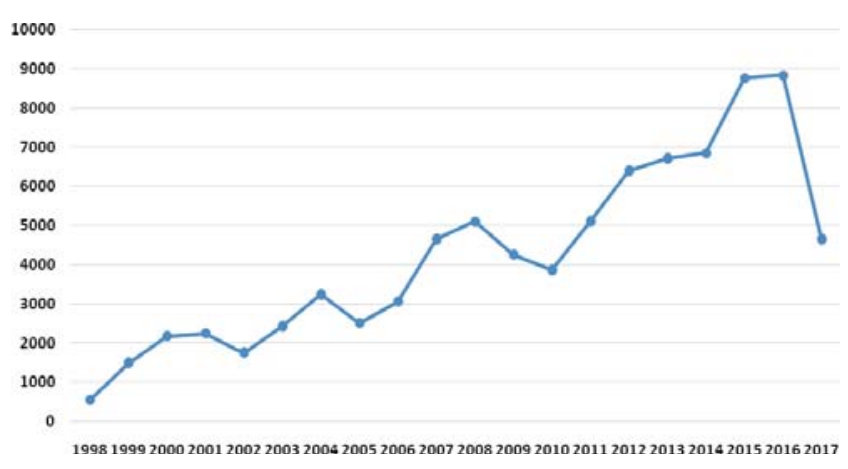

Рис. 1. Динамика цен на зерно пшеницы за 1998-2017 22., руб./m

почти вдвое, что привело к возникновению больших трудностей с реализацией продукции у большинства сельскохозяйственных товаропроизводителей со всеми вытекающими последствиями. В Саратовской области значительные объемы произведенного в 2017 г. зерна остались не реализованными и перешли в качестве товарных запасов на следующий год, обусловив недобор выручки и усиление дефицита финансовых оборотных ресурсов. Нежелание производителей продавать по низким ценам зерно обусловлено экономической нецелесообразностью, поскольку сложившиеся цены не позволяют на необходимом уровне окупить понесенные производственные затраты.

Постоянные колебания цен не только приводят к экономическим потерям, но и не стимулируют технико-технологическое развитие производства, поскольку становятся не окупаемыми не только затраты на применение удобрений и средств защиты растений, но и на приобретение современной сельскохозяйственной техники, тем более импортного производства [5]. У фермеров и предприятий значительно снижаются возможности стимулирования работников, применения систем мотивации, позволяющих привлекать и удерживать высококвалифицированные кадры в сельском хозяйстве [6]. Таким образом, колебания цен являются существенным фактором, негативно влияющим на развитие аграрного сектора экономики в долгосрочной перспективе.

Падение цен приводит к более негативным последствиям, чем падение урожайности из-за влияния различных факторов. Это подтверждается результатами выполненных расчетов на примере самой распространенной в нашем регионе зерновой культуры - озимой пшеницы (табл. 1) [4].

Расчеты производились на основе технологической карты возделывания озимой пшеницы ООО «К $(\Phi)$ Х Королев В.П.» Петровского района Саратовской области, согласно которой постоянные затраты на 1 га посева озимой пшеницы составляют почти 19 тыс. руб., а переменные, к которым были отнесены затраты на комплекс уборочных работ (комбайнирование, транспортировка и доработка зерна), примерно 15,6 руб. на 1 т. При данных затратах хозяйство уверенно планировало получить урожайность в 2017 г. в среднем 40 ц/га.
Рассматриваемое предприятие является одним из немногих в регионе, вкладывающих значительные средства в технико-технологическую модернизацию растениеводства и получающих высокие показатели урожайности культур. При запланированных затратах и урожайности в хозяйстве в 2017 г. гарантированно могли бы получить рентабельность производства зерна 40-50 \% при условии сохранения цен реализации на уровне 2016 г. (8500-9000 руб./т). Однако значительное падение цен реализации в 2017 г. привело к непланируемым отрицательным последствиям и хозяйство вынуждено было для покрытия самых острых потребностей в денежных ресурсах продать часть продукции в убыток по низким ценам, а часть оставить в товарном запасе, ожидая роста цены и имея дополнительные издержки на привлечение не запланированных заемных средств для финансирования текущей деятельности.

Графическое отображение результатов расчетов наглядно демонстрирует влияние изменений урожайности и цен на эффективность производства озимой пшеницы, в данном случае на такие показатели, как валовой и чистый доход в расчете на 1 га посева культуры (рис. 2).

Графики на диаграмме показывают, как будет меняться доходность данной культуры при возможном росте или снижении урожайности, а также точку безубыточности, которая соответствует уровню урожайности 25-26 ц/га. Это говорит о том, что расчетная зона безубыточного производства допускает снижение урожайности на 40-45 \% от запланированного уровня 40 ц/га, обеспечивая хозяйствам запас финансовой прочности в сфере производственных рисков. При этом, если цена на продукцию будет стабильной, то это, безусловно, будет стимулировать производителей за счет технических, технологических и организационных инноваций добиваться не только плановых показателей, но и увеличивать урожайность, так как связанное с этим увеличение затрат как на возделывание, так и на уборку культуры будет окупаться приростом урожая и стоимостью дополнительной продукции. Если же, рассчитать эффективность при снижении цены вдвое, как это и произошло в 2017 г., то мы видим, что точка безубыточности при осуществленных тех же постоянных и переменных затратах, сместится до уровня 6465 ц/га, что приводит к гарантированным убыткам производителей дажепри ростеурожайности на 60$65 \%$. Это лишает сельскохозяйственных товаропроизводителей запаса финансовой прочности и не стимулирует технологическое развитие отрасли на фоне нестабильности конъюнктуры цен.

Значительная реакция эффективности производства зерна на снижение цены наглядно видна и на графиках, отражающих уровень рентабельности (убыточности) в рассматриваемом диапазоне возможного изменения урожайности (рис. 3). На графике наглядно видно, что безубыточное произ- 


\begin{tabular}{|c|c|c|c|c|c|c|c|c|c|c|c|c|c|c|c|c|c|}
\hline \multirow{14}{*}{ 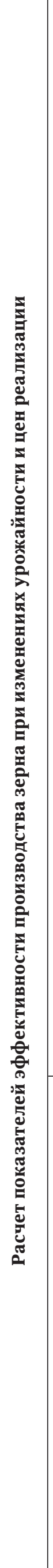 } & : & $\begin{array}{lll}0 \\
\end{array}$ & $\mid \begin{array}{l}0 \\
0 \\
\infty \\
\infty\end{array}$ & 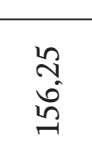 & ఏ్రి & 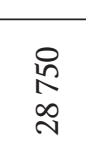 & ঃ & : & $\mid \begin{array}{l}\text { D. } \\
\text { o. } \\
\text { on }\end{array}$ & $\stackrel{\circ}{\circ}$ & 离 & & $\frac{5}{5}$ & \begin{tabular}{|c|}
8 \\
$\infty$ \\
$\infty$ \\
$\infty$
\end{tabular} & in & $a^{\circ}$ & 。̊ \\
\hline & 8 & $\begin{array}{lll}0 \\
0 \\
\end{array}$ & $\begin{array}{l}0 \\
1 \\
\infty \\
\infty \\
n\end{array}$ & 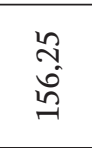 & 瓷 & 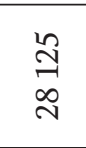 & ঃু & 要 & $\begin{array}{l}n \\
\infty \\
\infty \\
n \\
n \\
n\end{array}$ & $\stackrel{\circ}{\circ}$ & 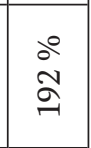 & & 多 & \begin{tabular}{|l|}
\multirow{2}{0}{} \\
N \\
\end{tabular} & \begin{tabular}{|l|}
\multirow{7}{*}{} \\
\end{tabular} & 宇 & ¿̊ \\
\hline & §̊ & in & $\begin{array}{l}0 \\
\substack{n \\
0 \\
\infty}\end{array}$ & 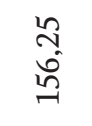 & p. & $\begin{array}{l}8 \\
\text { o } \\
\text { N }\end{array}$ & ঃু & $\begin{array}{l}8 \\
\vdots \\
0 \\
i n\end{array}$ & $\begin{array}{l}0 \\
\vdots \\
\text { iे }\end{array}$ & $\cong$ & $\begin{array}{l}\stackrel{\circ}{0} \\
\stackrel{\infty}{\infty}\end{array}$ & & 多 & 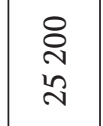 & 品 & $\stackrel{\circ}{\circ}$ & $\stackrel{\circ}{\circ}$ \\
\hline & ○े & in & $\mid \begin{array}{l}0 \\
0 \\
\infty \\
\infty \\
\sim\end{array}$ & 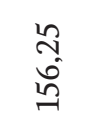 & $\frac{\pi}{\pi}$ & 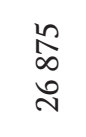 & ঃু & $\begin{array}{l}8 \\
0 \\
o \\
q\end{array}$ & 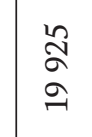 & 产 & 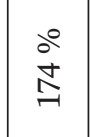 & & 亲 & 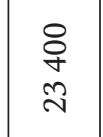 & 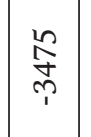 & $\stackrel{\circ}{\stackrel{9}{7}}$ & 高 \\
\hline & ণั & 赵 & $\mid \begin{array}{l}0 \\
\substack{R \\
\infty \\
\infty}\end{array}$ & 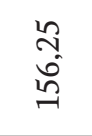 & o & 品 & ঃ & $\begin{array}{l}8 \\
\bar{\sigma} \\
\tilde{\gamma}\end{array}$ & 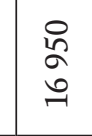 & $\therefore$ & $\begin{array}{l}\stackrel{\circ}{\circ} \\
\stackrel{3}{0}\end{array}$ & & 学 & $\begin{array}{l}\delta \\
\stackrel{0}{-} \\
-1\end{array}$ & 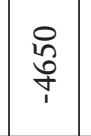 & $\stackrel{\circ}{\stackrel{\infty}{\rightarrow}}$ & ঐ̊ \\
\hline & 莺 & : & $=\begin{array}{l}0 \\
0 \\
\infty \\
\infty\end{array}$ & 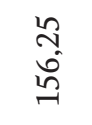 & $\begin{array}{l}10 \\
0 \\
0\end{array}$ & 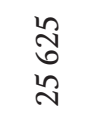 & ঃ & $\begin{array}{l}8 \\
0 \\
\text { m }\end{array}$ & $\begin{array}{l}n \\
2 \\
2 \\
\eta\end{array}$ & $\stackrel{\circ}{i n}$ & $\begin{array}{l}\stackrel{\circ}{\circ} \\
\text { hn }\end{array}$ & 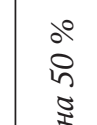 & 学 & \begin{tabular}{|c|} 
\\
0 \\
0 \\
\hdashline
\end{tabular} & 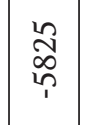 & 今े & $\stackrel{\circ}{\stackrel{0}{R}}$ \\
\hline & 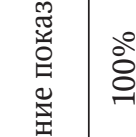 & 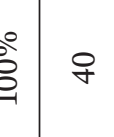 & $=\begin{array}{l}0 \\
0 \\
\infty \\
\infty\end{array}$ & 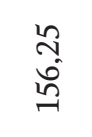 & ్ㅐㅇ & 各 & ঃ & $\begin{array}{l}\text { o } \\
\text { o }\end{array}$ & $\begin{array}{l}8 \\
= \\
=\end{array}$ & 守 & 発 & $\begin{array}{l}\text { 害 } \\
\text { 黑 }\end{array}$ & 学 & \begin{tabular}{l}
8 \\
0 \\
$\infty$ \\
\hdashline
\end{tabular} & $\mid \begin{array}{l}0 \\
\vdots \\
1 \\
1\end{array}$ & 定 & 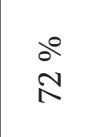 \\
\hline & 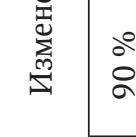 & 密 & $\mid \begin{array}{l}0 \\
\substack{R \\
0 \\
\infty}\end{array}$ & 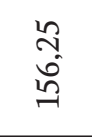 & బ్రి & 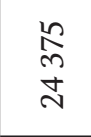 & ঃ & 吕 & 望 & ळ & 总 & 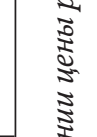 & 多 & 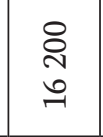 & 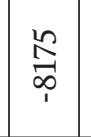 & 年 & ذ̊ㅇㅇ \\
\hline & $\stackrel{\infty}{\infty}$ & 总荅 & $\begin{array}{l}0 \\
D \\
\infty \\
\infty \\
\infty\end{array}$ & 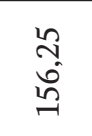 & 8 & 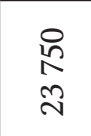 & ঃ & 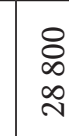 & 总 & $\stackrel{\circ}{\stackrel{9}{0}}$ & 㝏 & 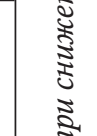 & 学 & \begin{tabular}{|l|} 
\\
\\
\\
\end{tabular} & 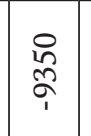 & 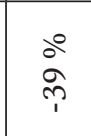 & $\stackrel{\circ}{\circ}$ \\
\hline & & ڤं & $\begin{array}{l}0 \\
0 \\
\infty \\
\infty \\
\sim\end{array}$ & 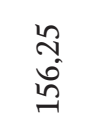 & 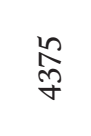 & 궘 & ঃ & 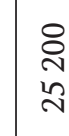 & 令 & $\therefore$ & 兽 & 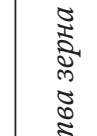 & b & $\begin{array}{l}\stackrel{8}{0} \\
\cong\end{array}$ & 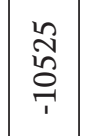 & 年 & $\stackrel{\circ}{\circ}$ \\
\hline & ¿̊ & 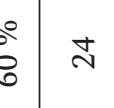 & $\mid \begin{array}{l}0 \\
0 \\
\infty \\
0\end{array}$ & 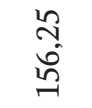 & in & 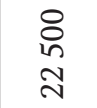 & ঃ & : & 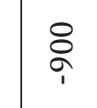 & $\stackrel{\circ}{\dot{\gamma}}$ & ळ & 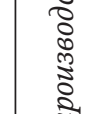 & 过 & $\begin{array}{l}\stackrel{8}{0} \\
\stackrel{0}{a}\end{array}$ & \begin{tabular}{|l|}
8 \\
0 \\
7
\end{tabular} & ڤั & 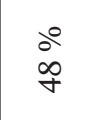 \\
\hline & & : & $\begin{array}{l}0 \\
1 \\
\infty \\
\infty\end{array}$ & 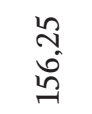 & $\stackrel{2}{\sim}$ & 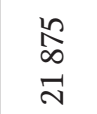 & ঃ & $\underset{\infty}{\stackrel{\infty}{\infty}}$ & 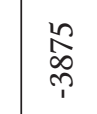 & $\begin{array}{l}\stackrel{0}{\infty} \\
\stackrel{\infty}{1}\end{array}$ & $\begin{array}{l}\stackrel{\circ}{\infty} \\
\stackrel{\infty}{\infty}\end{array}$ & 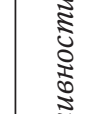 & 字 & ঃू & $\mid$\begin{tabular}{|c}
$\stackrel{n}{0}$ \\
$\stackrel{0}{7}$ \\
7
\end{tabular} & ڤั & $\begin{array}{l}\stackrel{\circ}{\sigma} \\
\vec{F}\end{array}$ \\
\hline & ஓे & : & $\begin{array}{l}0 \\
\substack{k \\
0 \\
\infty}\end{array}$ & $\begin{array}{l}\text { ñ } \\
\text { 品 }\end{array}$ & 品 & $\begin{array}{l}\stackrel{0}{0} \\
\text { N }\end{array}$ & ঃ & 吕 & 总 & $\stackrel{\circ}{\stackrel{\gamma}{~}}$ & $\begin{array}{l}\stackrel{\circ}{\circ} \\
\stackrel{0}{0}\end{array}$ & 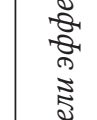 & 学 & 읏 & $\mid \begin{array}{l}0 \\
0 \\
o \\
1 \\
1\end{array}$ & 递 & 总 \\
\hline & 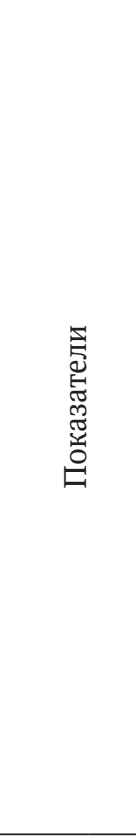 & 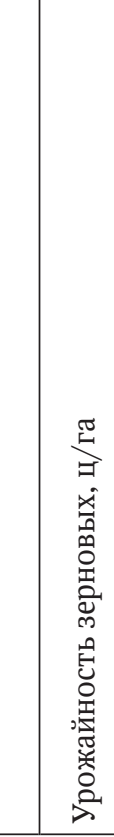 & 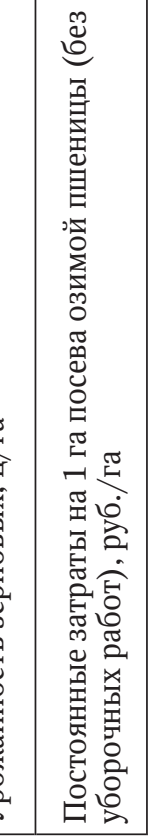 & 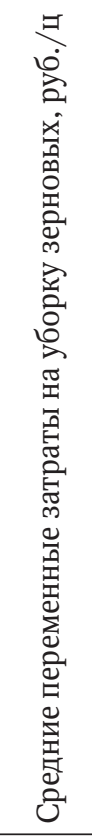 & 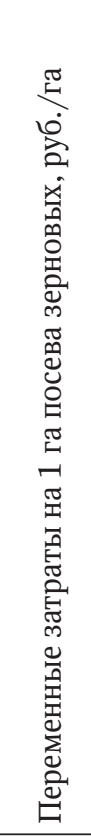 & 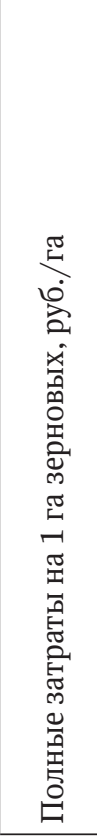 & 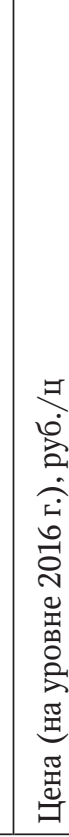 & 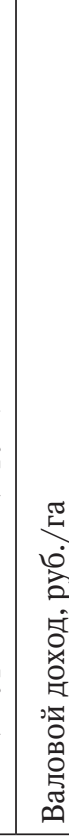 & 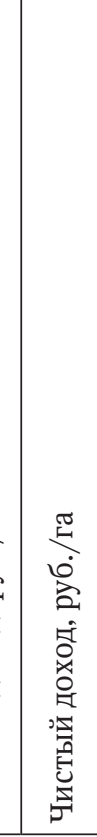 & 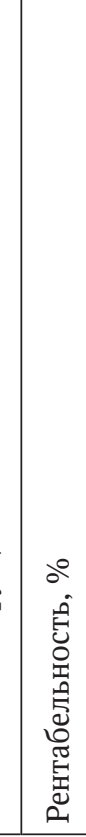 & 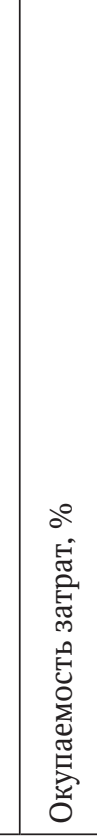 & 总 & 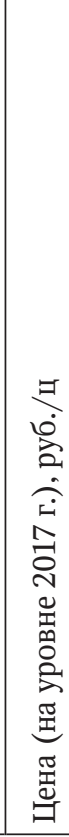 & 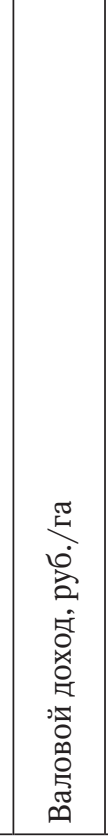 & 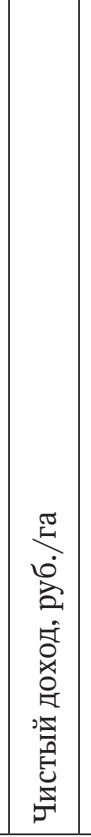 & 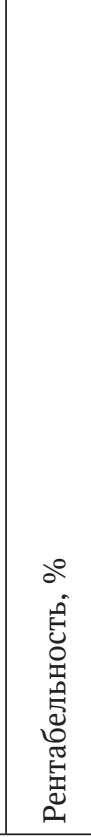 & 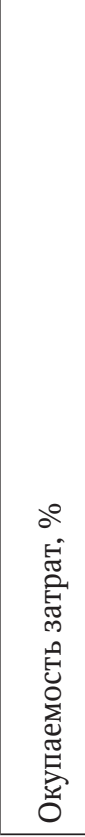 \\
\hline
\end{tabular}



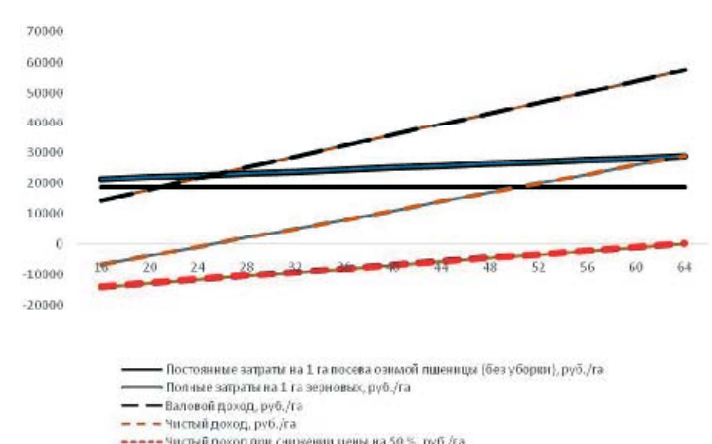

\section{Рис. 2. Доходность производства зерна озимой пшеницъ при изменении урожайности и цены}

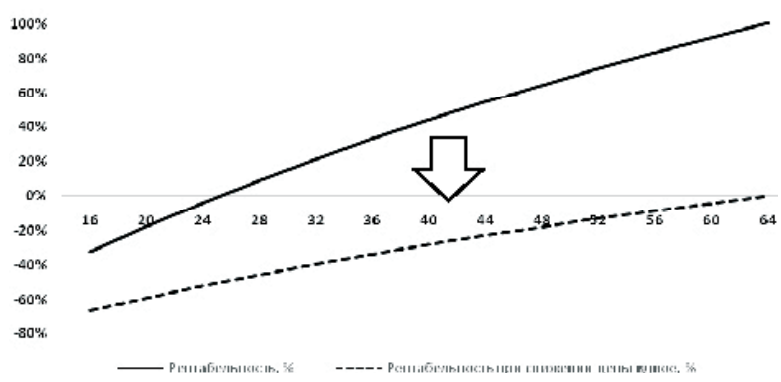

Рис. 3. Рентабельность производства зерна озимой пшеницы при изменении урожайности и цены

водство зерна озимой пшеницы с использованием современных технологий, удобрений и средств защиты растений при уровне цен, который сложился осенью 2017 г. в условиях Саратовской области возможно при достижении урожайности свыше 60 ц/га. Это практически недостижимые условия для большинства сельскохозяйственных товаропроизводителей, особенно средних и мелких размеров.

Недостижимость параметров эффективного производства зерна связана с тем, что добиться устойчиво такого уровня урожайности можно только при благоприятных погодно-климатических условиях и с тем, что для обеспечения данной урожайности в технологию возделывания культуры необходимо вложить значительные оборотные средства, хронический дефицит которых является постоянной проблемой отечественного сельского хозяйства на фоне постоянно высокой стоимости заемных финансовых ресурсов и их ограниченной доступности для малого и среднего агробизнеса.

Таким образом, в настоящее время колебания цен на сельскохозяйственную продукцию являются главным дестабилизирующим фактором устойчивого и эффективного развития агробизнеса как в Саратовской области, так и в России в целом. Таких колебаний цен нет больше ни в одной сфере экономики, что делает агробизнес в нашей стране самым рискованным видом предпринимательской деятельности, подверженной сильному влиянию производственных и коммерческих рисков. При этом коммерческие риски, связанные с колебанием цен приводят не только к финансо- вым потерям товаропроизводителей в периоды ценового провала, но и не способствуют развитию отрасли в долгосрочной перспективе, сдерживая инвестиционные вложения в технико-технологическую модернизацию растениеводства и ограничивая применение элементов прогрессивных инновационных технологий (интенсивные сорта и гибриды культур, удобрения, средства защиты растений и т.п.).

Заключение. Многие сельскохозяйственные товаропроизводители в условиях колебания цен просто не видят смысла вкладывать в рост урожайности, понимая, что затраты могут не окупиться при обвале цен, как это в очередной раз произошло в 2017 г. В связи с этим многие, особенно средние и мелкие фермеры, предпочитают рисковать как можно меньше и возделывают культуры по простым малозатратным технологиям, без применения новых сортов и гибридов, удобрений и средств защиты растений. Это, конечно же, не позволит получать высокие урожаи и доходы, но и возможные финансовые потери, в виде неокупаемой части понесенных затрат при снижении цен, также значительно ниже. Крупные предприятия в этой ситуации чувствуют себя устойчивее, поскольку качественно другой уровень механизации технологических процессов в крупном растениеводстве, позволяет получать продукции с более низкой себестоимостью. Они могут себе позволить приобретение высокопроизводительной современной техники, имея больший доступ к финансовым ресурсам и лизинговым формам финансирования $[1,3]$. Однако при колебаниях цен и крупный агробизнес несет значительные финансовые потери.

На основании вышеизложенного можно сделать вывод о том, что в современных условиях стабилизацию ценовой конъюнктуры на сельскохозяйственных рынках следует считать главной задачей, решение которой позволит создать условия для устойчивого развития стратегически важного аграрного сектора экономики.

\section{СПИСОК ЛИТЕРАТУРЫ}

1. Бутылин В.В., Бутылина Ю.А., Черненко Е.В., Моренова Е.А. Совершенстование лизинга как регулятора развития материально-технической базы сельского хозяйства // Новые регуляторы развития АПК РФ: сб. ст. Междунар. науч.-практ. конф. - Саратов, 2017. С. 25-29.

2. Бутырин В.В., Бутытрина Ю.А., Черненко Е.В., Моренова Е.А. Мотивационные аспекты управленческой деятельности на предприятиях агропромышленного комплекса //Аграрный научный журнал. - 2017. - № 12. C. $82-85$.

3. Бутырин В.В., Горбунов В.С. Крупные сельскохозяйственные предприятия - основа агроэкономики // АПК: Экономика, управление. - 2013. - № 3. - С. 55.

4. Федеральная служба государственной статистики. Электронный ресурс. - Режим доступа: http:// www.gks.ru/. 
5. Храмченкова А.О. Актуализация методики нормирования механизированных полевых работ, выполняемых современной импортной техникой // Агропродовольственная политика России. - 2016.№ $10-(58)$. - С. 23-25.

6. Храмченкова А.О. Стимулирование труда работников сельскохозяйственных предприятий в условиях рынка: дис. ... канд. экон. наук; Российский государственный аграрный университет Московская сельскохозяйственная академия им. К.А. Тимирязева. - М., 2000. -Режим доступа: https:// elibrary.ru/author items.asp.

Бутырин Василий Владимирович, д-р экон. наук, проф. кафедры «Организация производства и управления бизнесом в АПК», Саратовский государственный аграрный университет имени Н.И. Вавилова. Россия.
Бутырина Юлия Александровна, канд. экон. наук, доцент кафедры «Организация производства и управления бизнесом в АПК», Саратовский государственный аграрный университет имени Н.И. Вавилова. Россия.

Моренова Елена Александровна, канд. экон. наук, доцент кафедры «Менеджмент в АПК», Саратовский государственный аграрный университет имени Н.И. Вавилова. Россия.

Черненко Елена Владимировна, канд. экон. наук, доиент кафедры «Менеджмент в АПК», Саратовский государственный аграрный университет имени Н.И. Вавилова. Россия.

10012, г. Саратов, Театральная пл., 1.

Тел.: (8452) 26-27-83., e-mail: el.chernenko@yandex.ru

Ключевъе слова: агробизнес; растениеводство; колебания иен; эффективность; рентабельность.

\title{
PRICE FLUCTUATIONS INFLUENCE ON AGRIBUSINESS DEVELOPMENT
}

Butyrin Vasily Vladimirovich, Doctor of Economic Sciences, Professor of the chair "Production Organization and Business Management in Agriculture”, Saratov State Agrarian University named after N.I. Vavilov. Russia.

Butyrina Yulia Alexandrovna, Candidate of Economic Sciences, Associate Professor of the chair "Production Organization and Business Management in Agriculture”, Saratov State Agrarian University named after N.I. Vavilov. Russia.

Morenova Elena Aleksandrovna, Candidate of Economic Sciences, Senior Teacher of the chair "Management in Agrarian and Industrial Complex”, Saratov State Agrarian University named after N.I. Vavilov. Russia.

Chernenko Elena Vladimirovna, Candidate of Eco- nomic Sciences, Senior Teacher of the chair "Management in Agrarian and Industrial Complex”, Saratov State Agrarian University named after N.I. Vavilov. Russia.

Keywords: agribusiness; crop production; price fluctuations; efficiency; profitability.

The influence of various factors on the efficiency of agricultural production on the example of crop production is considered. On the basis of calculations it is proved that the most powerful impact on the efficiency and development of agribusiness is provided by price fluctuations in agricultural markets.

Удк 338.433(045)

\section{АНАЛИЗ ПРОБЛЕМ РАЗВИТИЯ ОТЕЧЕСТВЕННОГО АПК И ОСОБЕННОСТЕЙ ПРОВЕДЕНИЯ ПРОЦЕДУР БАНКРОТСТВА}

\author{
ДАНИЛОВА Наталия Федоровна, Саратовский социально-экономический институт (филиал) \\ РЭУ им. Г.В. ПлеХанова
}

КАБАНЦЕВА Наталия Гавриловна, Саратовский национальный исследовательский государственный университет имени Н.Г. Чернышевского.

САРАЕВА Ирина Викторовна, Саратовский социально-экономический институт (филиал)

РЭУ им. Г.В. Плеханова

Рассматриваются проблемы развития отечественного АПК, в том числе проблемы несостоятельности сельхозтоваропроизводителей. Выделены факторы, обусловливающие низкие темпы развития отечественного агропромышленного комплекса. Дан анализ процедуры банкротства, сделаны выводы по проблемам развития отечественного АПК и особенностям проведения процедур банкротства в отнощении сельхозтоваропроизводителей.

Введение. Исследования, проводимые отечественными и зарубежными специалистами, показали, что АПК является важнейшим звеном мировогохозяйства в целом и отдельных стран в частности, в нем производится жизненно важная для граждан продукцияи сосредоточен огромный экономических потенциал. Предметом исследования является методический аппарат оценки риска банкротства российскихсельскохозяйственных предприятий (организаций).
Методика исследований. Исследование основано на диалектической теории научного познания, единстве логического анализа и исторического развития. В работе использованы системный подход, дедукция и индукция, методы экономического и статистического анализа, современные методы построения экономических моделей.

Резулътаты исследований. Изучение широкого спектра отечественных и зарубежных публикаций и материалов, посвященных исследованию 